Article

\title{
Facile Synthesis of ZnO Nanoparticles on Nitrogen-Doped Carbon Nanotubes as High-Performance Anode Material for Lithium-Ion Batteries
}

\author{
Haipeng Li ${ }^{1}$, Zhengjun Liu ${ }^{1}$, Shuang Yang ${ }^{1}$, Yan Zhao ${ }^{1, *}$, Yuting Feng ${ }^{2}$, \\ Zhumabay Bakenov $^{3}$ (D), Chengwei Zhang ${ }^{1, *}$ and Fuxing Yin ${ }^{1}$ \\ 1 School of Materials Science \& Engineering, Research Institute for Energy Equipment Materials, \\ Tianjin Key Laboratory of Materials Laminating Fabrication and Interface Control Technology, \\ Hebei University of Technology, Tianjin 300130, China; lihp_hebut@outlook.com (H.L.); \\ lzj125@126.com (Z.L.); hebutyangshuang@163.com (S.Y.); yinfuxing@hebut.edu.cn (F.Y.) \\ 2 Synergy Innovation Institute of GDUT, Heyuan 517000, China; 18222385469@163.com \\ 3 Institute of Batteries LLC, Nazarbayev University, 53 Kabanbay Batyr Avenue, Astana 010000, Kazakhstan; \\ zbakenov@nu.edu.kz \\ * Correspondence: yanzhao1984@hebut.edu.cn (Y.Z.); zhangpan0411@sina.com (C.Z.)
}

Received: 17 August 2017; Accepted: 4 September 2017; Published: 21 September 2017

\begin{abstract}
ZnO} /$ nitrogen-doped carbon nanotube $(\mathrm{ZnO} / \mathrm{NCNT})$ composite, prepared though a simple one-step sol-gel synthetic technique, has been explored for the first time as an anode material. The as-prepared $\mathrm{ZnO} / \mathrm{NCNT}$ nanocomposite preserves a good dispersity and homogeneity of the $\mathrm{ZnO}$ nanoparticles $(\sim 6 \mathrm{~nm})$ which deposited on the surface of NCNT. Transmission electron microscopy (TEM) reveals the formation of $\mathrm{ZnO}$ nanoparticles with an average size of $6 \mathrm{~nm}$ homogeneously deposited on the surface of NCNT. ZnO/NCNT composite, when evaluated as an anode for lithium-ion batteries (LIBs), exhibits remarkably enhanced cycling ability and rate capability compared with the $\mathrm{ZnO} / \mathrm{CNT}$ counterpart. A relatively large reversible capacity of $1013 \mathrm{mAh} \cdot \mathrm{g}^{-1}$ is manifested at the second cycle and a capacity of $664 \mathrm{mAh} \cdot \mathrm{g}^{-1}$ is retained after 100 cycles. Furthermore, the $\mathrm{ZnO} / \mathrm{NCNT}$ system displays a reversible capacity of $308 \mathrm{mAh} \cdot \mathrm{g}^{-1}$ even at a high current density of $1600 \mathrm{~mA} \cdot \mathrm{g}^{-1}$. These electrochemical performance enhancements are ascribed to the reinforced accumulative effects of the well-dispersed $\mathrm{ZnO}$ nanoparticles and doping nitrogen atoms, which can not only suppress the volumetric expansion of $\mathrm{ZnO}$ nanoparticles during the cycling performance but also provide a highly conductive NCNT network for $\mathrm{ZnO}$ anode.
\end{abstract}

Keywords: lithium ion battery; anode; $\mathrm{ZnO} /$ nitrogen-doped carbon nanotube ( $\mathrm{ZnO} / \mathrm{NCNT})$ composite; highly-dispersed $\mathrm{ZnO}$ nanoparticles; sol-gel

\section{Introduction}

Lithium-ion batteries (LIBs) have been widely used as energy sources because of their high energy density and excellent recycling time [1-4]. In recent years, graphite has become the main commercial anode material for LIBs. However, its relatively low capacity $372 \mathrm{mAh} \cdot \mathrm{g}^{-1}$ (theoretical value) limits further development of LIB [5]. Significant attention has been focused on the research of next-generation promising anode candidates to replace graphite. Transition metal oxides $\left(\mathrm{MO}_{\mathrm{x}}\right.$, where $\mathrm{M}$ is $\mathrm{Fe}, \mathrm{Co}, \mathrm{Ni}, \mathrm{Cu}, \mathrm{Zn}$, etc.) have been considered as new type alternative anode materials for next-generation high-capacity LIB due to their high theoretical capacity [6]. Particularly, nontoxic zinc oxide $(\mathrm{ZnO})$ has received considerable attention owing to its outstanding advantages, such as high theoretical capacity $\left(978 \mathrm{mAh} \cdot \mathrm{g}^{-1}\right)$, nontoxicity, low processing cost, and chemical stability. Despite 
of these merits, the potential application of $\mathrm{ZnO}$ anode is limited by the sever capacity fading, poor cycling stability, and high irreversible capacity, which are caused by its agglomeration/pulverization and large volume expansion/contraction during the cycling process [7-9]. Moreover, its unsatisfactory electrical conductivity suppresses fast lithium diffusion, leading to poor lithium storage behavior [10].

Up to now, many strategies have been researched to overcome mentioned drawbacks of $\mathrm{ZnO}$ based anodes. One of the strategies is to utilize nanostructure features in the material, which can improve mechanical durability of $\mathrm{ZnO}$ and shorten the diffusion paths for $\mathrm{Li}$ ion transport, thereby improving cycling performance and facilitating fast lithium-ion diffusion $[7,11]$. Nevertheless, nanostructured $\mathrm{ZnO}$ with the high surface area favors side reaction with the electrolyte, which leads to irreversible capacity loss during the initial cycle. Furthermore, this approach is insufficient to ameliorate the poor electric conductivity of $\mathrm{ZnO}$ sufficiently $[12,13]$. In order to further solve the shortcomings of the $\mathrm{ZnO}$ anodes, nanostructured $\mathrm{ZnO}$ could be combined with a highly conductive and elastic matrix to form a nanocomposite structure. In the past few years, various hybrid nanostructures of $\mathrm{ZnO}$ have been developed, such as carbon/ZnO nanorods [14], ZnO/mesoporous carbon [15], ZnO@Graphene [16], and $\mathrm{ZnO} /$ carbon nanotube $(\mathrm{ZnO} / \mathrm{CNT})$ [7]. Ren et al. reported that the carbon-encapsulated $\mathrm{ZnO}$ tetrahedron were synthesized via a simple internal-reflux approach, and this composite anode demonstrated a desirable capacity of $518 \mathrm{mAh} \cdot \mathrm{g}^{-1}$ at a current density of $110.7 \mathrm{~mA} \cdot \mathrm{g}^{-1}$ [17]. Guler et al. reported that the $\mathrm{ZnO} / \mathrm{CNT}$ nanocomposites were prepared via thermal evaporation techniques followed by an in situ plasma oxidation, and the reversible capacities could be retained as $527 \mathrm{mAh} \cdot \mathrm{g}^{-1}$, even after 100 cycles [18]. Among the other conducting agents, CNT has been considered to be a very promising one, which could form a conductive network and buffer the volume expansion of $\mathrm{ZnO}$ upon cycling [19-21]. However, due to the inert nature of CNT, it is difficult to obtain highly homogeneously dispersed metal oxide composite via common techniques. Recently, Qin et al. [22-24] reported that nitrogen doping of CNT could improve its surface activity and provide more nucleation sites to disperse metal oxide on its surface, which facilitates the morphology and particle size control of the hybrids. Specifically, nitrogen doping is considered as a feasible way to promote effectively the conductivity and reactivity of carbonaceous materials, which will increase electrochemical properties and reversible capacity of the hybrids, as has been experimentally and theoretically studied [25-27]. However, to our knowledge, only a few studies have been reported to date on synthesis and electrochemical properties of $\mathrm{ZnO}$ nanoparticles deposited on nitrogen-doped carbon nanotube (NCNT).

Herein, we report on a simple environmentally friendly sol-gel method for homogeneous deposition of $\mathrm{ZnO}$ nanoparticles on the NCNT surface, and investigation of physical and electrochemical performance of the resulted $\mathrm{ZnO} / \mathrm{NCNT}$ composite as an anode for laboratory scale lithium-ion cells.

\section{Materials and Methods}

\subsection{Chemical Materials}

Zinc acetate $\left(\mathrm{Zn}\left(\mathrm{CH}_{3} \mathrm{COO}\right)_{2}, \geq 99 \%\right.$, Tianjin Fuchen Chemical Reagents Factor), lithium hydroxide ( $\mathrm{LiOH}, \geq 90 \%$, Tianjin Guangfu Fine Chemical Research Institution) and ethanol $\left(\mathrm{C}_{2} \mathrm{H}_{5} \mathrm{OH}, \geq 99.7 \%\right.$, Tianjin Fuchen Chemical Reagents Factor) were used as metal-ion source, catalyst, and solvent, respectively. Carbon nanotubes (CNT, Tianjin Guangfu Fine Chemical Research Institution) and nitrogen-doped carbon nanotubes (NCNT, N content 2.98\%, Tianjin Guangfu Fine Chemical Research Institution) were used as a conductive supportive matrix.

\subsection{Preparation of $\mathrm{ZnO} / \mathrm{NCNT}$ and $\mathrm{ZnO} / \mathrm{CNT}$}

The synthetic procedures for $\mathrm{ZnO} / \mathrm{NCNT}$ and $\mathrm{ZnO} / \mathrm{CNT}$ were adopted from the literature [28]. The $\mathrm{ZnO} / \mathrm{NCNT}$ nanocomposite was fabricated by the sol-gel route. Briefly, $\mathrm{Zn}\left(\mathrm{CH}_{3} \mathrm{COO}\right)_{2}$ and $\mathrm{LiOH}$ (molar ratio $=1.3: 1)$ were dissolved separately in $130 \mathrm{dm}^{3}$ ethanol with magnetic agitation at room temperature until the reagents were completely dissolved. The $\mathrm{Zn}\left(\mathrm{CH}_{3} \mathrm{COO}\right)_{2}-\mathrm{LiOH}$ mixed system 
was formed by adding the $\mathrm{LiOH}$ solution to the $\mathrm{Zn}\left(\mathrm{CH}_{3} \mathrm{COO}\right)_{2}$ solution dropwise under agitation on a magnetic stirrer for $30 \mathrm{~min}$ at room temperature. Subsequently, $0.085 \mathrm{~g}$ NCNT was added to the mixture solution. This resulted in formation of black sol, which was continued stirring for $24 \mathrm{~h}$. The black sediment of $\mathrm{ZnO} / \mathrm{NCNT}$ was obtained through filtering separation, alternately cleaned with distilled water and ethanol for several times. Then, it was dried in vacuum at $60{ }^{\circ} \mathrm{C}$ for $12 \mathrm{~h}$. The preparation of $\mathrm{ZnO} / \mathrm{CNT}$ was same as described for $\mathrm{ZnO} / \mathrm{NCNT}$ with substitution of CNT for NCNT.

\subsection{Material Characterizations}

The samples crystalline structure was examined by X-ray diffraction (XRD) on a Rigaku Corporation Smartlab system (Tokyo, Japan) with $\mathrm{Cu}-\mathrm{K} \alpha$ radiation $(\lambda=0.15418 \mathrm{~nm})$ source, and their morphology and structure were investigated by means of transmission electron microscopy (TEM, JEM-2100F, JEOL, Tokyo, Japan) and scanning electron microscopy (SEM, Hitachi Limited S-4800, Tokyo, Japan). Surface elemental analysis was carried out by an energy dispersive X-ray spectroscopy (EDX) attached to the SEM apparatus. X-ray photoelectron spectroscopy (XPS) measurements of the samples were recorded on a Thermo K-Aepna Ultra spectrometer (Waltham, MA, USA) with an Mg-K $\alpha$ excitation source. Thermo-gravimetric (TG, SDT Q-600, TA Instruments-Waters LLC, Newcastle, PA, USA) analysis was conducted from room temperature to $1000{ }^{\circ} \mathrm{C}$ under air with a heating rate of $10{ }^{\circ} \mathrm{C} \min ^{-1}$.

\subsection{Electrochemical Measurements}

A two-electrode CR2025 coin cells were assembled in a glovebox (MBraun) filled with argon and employed to assess the electrochemical performance of the samples. The working electrodes were obtained by a slurry coating process. The slurries were formed by mixing active materials (ZnO/NCNT or $\mathrm{ZnO} / \mathrm{CNT}$ ), carbon black (CB), and polyvinylidene fluoride (PVDF) with a mass ratio of 80:10:10 in $N$-methyl-2-pyrrolidine (NMP). The resulting homogenously slurries were coated on copper foil which served as current collector and dried at $60^{\circ} \mathrm{C}$ under a vacuum oven for $12 \mathrm{~h}$ to remove solvent and water. Then the working electrodes were cut with $1.5 \mathrm{~cm}$ diameter and a mass loading of $\sim 0.85 \mathrm{mg} \mathrm{cm}^{-2}$ as the anode. The pure lithium metal foil was used as reference electrode. The polypropylene micro-porous film (Cellgard 2300) was used as a separator. The electrolyte was $1.0 \mathrm{M} \mathrm{LiPF}_{6}$ dissolved in a mixture of ethylene carbonate/diethylcarbonate/dimethylcarbonate (EC/DEC/DMC) (1:1:1 by volume). Galvanostatic charge-discharge tests were detected on NEWARE battery test system (Shenzhen, China) with a potential range from 0.005 and $3.0 \mathrm{~V} \mathrm{vs.} \mathrm{Li} / \mathrm{Li}^{+}$, at a wide range of current rates.

\section{Results and Discussion}

The XRD patterns of the as-prepared samples are presented in Figure 1a. In the XRD patterns of the $\mathrm{ZnO} / \mathrm{CNT}$ composite and $\mathrm{ZnO} / \mathrm{NCNT}$ composite, the location and intensity of the diffraction peaks-which are present at $31.7^{\circ}, 34.4^{\circ}, 36.2^{\circ}, 47.5^{\circ}, 56.6^{\circ}, 62.8^{\circ}, 66.4^{\circ}, 67.9^{\circ}$, and $69.0^{\circ}$ —can be indexed into (100), (002), (101), (102), (110), (103), (200), (112), and (201) crystal planes of pure wurtzite-type hexagonal ZnO (JCPDS No. 65-3411) [29]. Besides, the diffraction peaks are considerably sharp, suggesting the high crystalline $\mathrm{ZnO}$ of the composites. A weak peak at $2 \theta=26.2^{\circ}$ corresponds to the (002) plane of the hexagonal graphite structure (JPDS No. 41-1487), which is similar to that of CNT [30]. It can be seen that there is a slight peak shift of $\mathrm{ZnO} / \mathrm{NCNT}$ compared with $\mathrm{ZnO} / \mathrm{CNT}$ (inset of Figure 1a) towards lower angles, which is caused by the N doping on CNT. To demonstrate the variation of the $\mathrm{ZnO}$ crystal structure, the lattice spacing was calculated according to Bragg's formula based on the strongest diffraction peak of (101), and it was found that the lattice fringe spacing changes from 0.247 to $0.252 \mathrm{~nm}$ [31]. Compared with the original $\mathrm{ZnO}$ crystal, the increased lattice distance of $\mathrm{ZnO}$ can provide much more active space and shorten the diffusion distance during the Li-ion insertion/extraction [32]. XPS was used to determine the chemical states of $\mathrm{C}$ and $\mathrm{N}$ in the $\mathrm{ZnO} / \mathrm{NCNT}$. 
The $\mathrm{C}$ 1s region XPS spectrum (Figure $1 \mathrm{~b}$ ) are corresponding to the three broad peaks at 284.2, 285.3, and $288.4 \mathrm{eV}$, which can be conformed into the $\mathrm{C}-\mathrm{C}, \mathrm{C}-\mathrm{O}$, and $\mathrm{C}-\mathrm{N}$ species, respectively $[33,34]$. The nitrogen atomic content in the $\mathrm{ZnO} / \mathrm{NCNT}$ composite was displayed by XPS analysis as $1.87 \%$, confirming the presence of nitrogen in the composite. It was reported that $\mathrm{N}$ doping on CNT can induce chemical adsorption of $\mathrm{ZnO}$ nanoparticles on its surface and afford a feasible pathway for $\mathrm{Li}$ ions transportation [35]. In order to determine the contents of $\mathrm{ZnO}$ in $\mathrm{ZnO} / \mathrm{CNT}$ and $\mathrm{ZnO} / \mathrm{NCNT}$ composites, the TG data is collected and illustrated in Figure 1c. Slight weight losses below $150{ }^{\circ} \mathrm{C}$ is attributed to dehydration of the starting materials. Major weight losses from about $175^{\circ} \mathrm{C}$ to $800^{\circ} \mathrm{C}$ are related to the combustion of NCNT and CNT. It can be observed that when the temperature exceeds $800{ }^{\circ} \mathrm{C}$, there are no significant change in the samples weight. Hence, the contents of $\mathrm{ZnO}$ in the $\mathrm{ZnO} / \mathrm{NCNT}$ and $\mathrm{ZnO} / \mathrm{CNT}$ composites are calculated to be about $75 \mathrm{wt} \%$ and $79.5 \mathrm{wt} \%$, respectively.
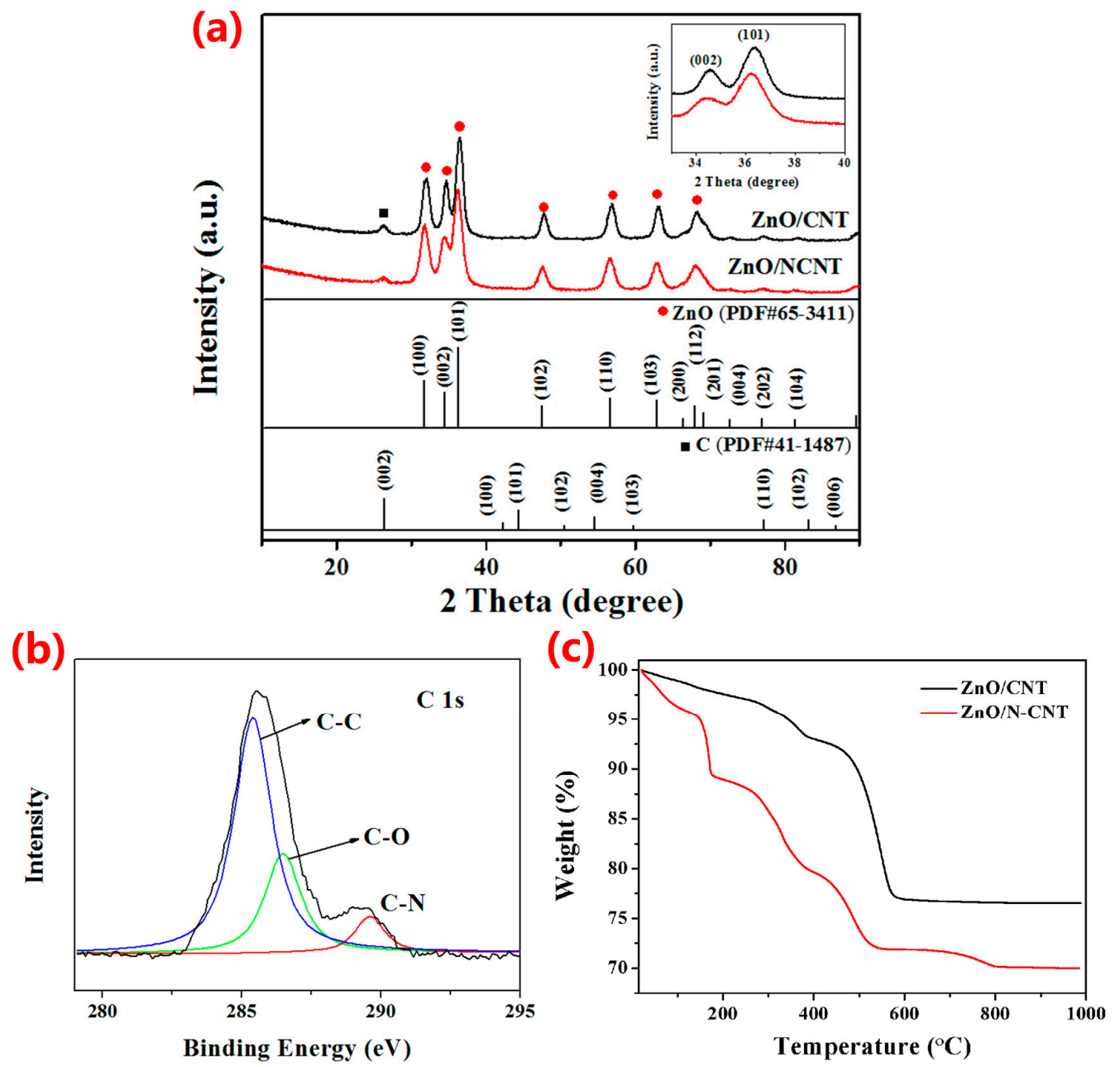

Figure 1. (a) XRD patterns of $\mathrm{ZnO} / \mathrm{NCNT}$ and $\mathrm{ZnO} / \mathrm{CNT}$ composites; inset: enlarged picture of XRD peaks appearing at $33-40^{\circ}$; (b) High-resolution XPS spectrum of $\mathrm{C} 1 \mathrm{~s}$ of the $\mathrm{ZnO} / \mathrm{NCNT}$ composite; (c) TG curves of the $\mathrm{ZnO} / \mathrm{NCNT}$ and $\mathrm{ZnO} / \mathrm{CNT}$ composites at a heating rate of $10^{\circ} \mathrm{C} \mathrm{min}{ }^{-1}$ under air.

To further characterize the morphologies of the $\mathrm{ZnO} / \mathrm{CNT}$ and $\mathrm{ZnO} / \mathrm{NCNT}$ composites, TEM was conducted to analyze the size and dispersion of $\mathrm{ZnO}$ nanoparticles within the samples. As revealed by the TEM images of $\mathrm{ZnO} / \mathrm{CNT}$ and $\mathrm{ZnO} / \mathrm{NCNT}$ composites (Figure 2a-d), one can easily find that the surfaces of both composites are covered by a layer of $\mathrm{ZnO}$ nanoparticles. However, the $\mathrm{ZnO}$ nanoparticles of $\mathrm{ZnO} / \mathrm{CNT}$ sample display obvious agglomeration, which may increase the negative effect of the volume expansion during the $\mathrm{Li}$ ions intercalation/deintercalation process on cycling 
performance of the material [36]. It is noticed that the $\mathrm{ZnO} / \mathrm{NCNT}$ sample shows more uniform dispersion of $\mathrm{ZnO}$ nanoparticles with a finer particle size $(6.2 \mathrm{~nm})$ than that of $\mathrm{ZnO} / \mathrm{CNT}$ sample $(8.2 \mathrm{~nm})$ (the inset of Figure $2 \mathrm{a}, \mathrm{c}$ ). This phenomenon could be attributed to the alteration of CNT surface properties by nitrogen doping, enhancing its activity and providing more nucleation sites [23]. It could be suggested that the $\mathrm{N}$-doping of $\mathrm{CNT}$, favoring the uniformity of the $\mathrm{ZnO}$ nanoparticles dispersion, can ameliorate the electronic conductivity of the composite and its Li-ion storing capability [37]. Crystal lattice fringes spacing of 0.248 and $0.261 \mathrm{~nm}$ can be noticed in the HR-TEM image of the $\mathrm{ZnO} / \mathrm{NCNT}$ composite (Figure 2e), which corresponds to the (101) and (002) plane of $\mathrm{ZnO}$, respectively. Figure $2 \mathrm{f}$ displays a SEM image of $\mathrm{ZnO} / \mathrm{NCNT}$ composite, more clearly the uniform dispersion state of $\mathrm{ZnO}$ in the $\mathrm{ZnO} / \mathrm{NCNT}$ composite can be observed. The EDX mapping (the inset of Figure $2 \mathrm{f}$ ) indicates that $\mathrm{ZnO} / \mathrm{NCNT}$ composite contains homogeneously distributed C, N, O, and Zn.

To evaluate the electrochemical properties of the prepared composites, $\mathrm{ZnO} / \mathrm{NCNT}$ and $\mathrm{ZnO} / \mathrm{CNT}$ composites were investigated by galvanostatic cycling in lithium half-cells in potential range of $0.005-3.0 \mathrm{~V}$ vs. $\mathrm{Li} / \mathrm{Li}^{+}$. The initial three charge/discharge curves of the $\mathrm{ZnO} / \mathrm{NCNT}$ and $\mathrm{ZnO} / \mathrm{CNT}$ composites at a current density of $100 \mathrm{~mA} \cdot \mathrm{g}^{-1}$ are exhibited in Figure 3 . As shown in Figure $3 \mathrm{a}$, the presence of a prolonged potential plateau at $0.4-0.5 \mathrm{~V}$ in the first cycle discharge stage could be ascribed to the decomposition of electrolyte and the formation of solid electrolyte interface (SEI) [38]. The SEI formation causes a low coulombic efficiency and an irreversible capacity loss at the first cycle: the first discharge and charge capacities of the $\mathrm{ZnO} / \mathrm{NCNT}$ composite are $1727 \mathrm{mAh} \cdot \mathrm{g}^{-1}$ and $1005 \mathrm{mAh} \cdot \mathrm{g}^{-1}$, respectively, which results in an initial coulombic efficiency of $58 \%$. From the following cycle, the prolonged plateau of SEI formation is not observed and there is only a discharge plateau with an average voltage of about $0.6 \mathrm{~V}$, attributed to the formation of $\mathrm{Zn}-\mathrm{Li}$ alloy [39]. It can be seen that there is no obvious capacity fading, suggesting a relatively steady state of the lithiation/delithiation process [36]. Meanwhile, a plateau around $0.1 \mathrm{~V}$ can be observed in the second and third discharge curves of the $\mathrm{ZnO} / \mathrm{NCNT}$ composite due to contribution of the carbon matrix into the lithiation process [17]. Compared with $\mathrm{ZnO} / \mathrm{NCNT}$ composite, $\mathrm{ZnO} / \mathrm{CNT}$ shows shorter plateaus and lower capacities (Figure 3b). It illustrates that N-doping of CNT plays an important role in maintaining battery capacities.
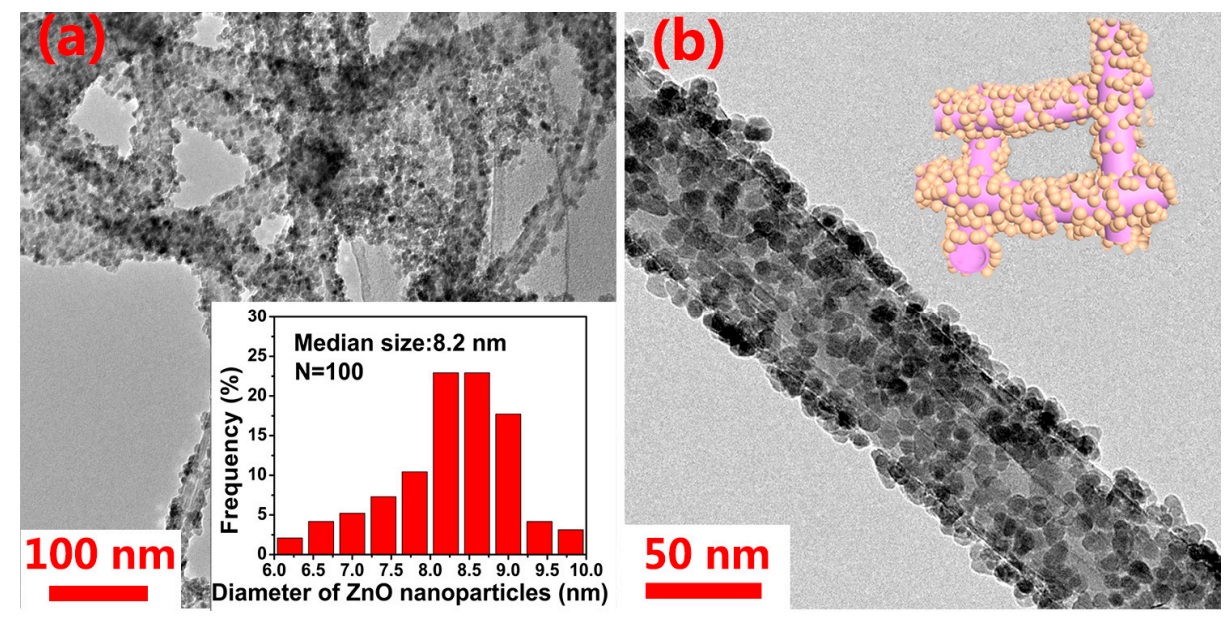

Figure 2. Cont. 


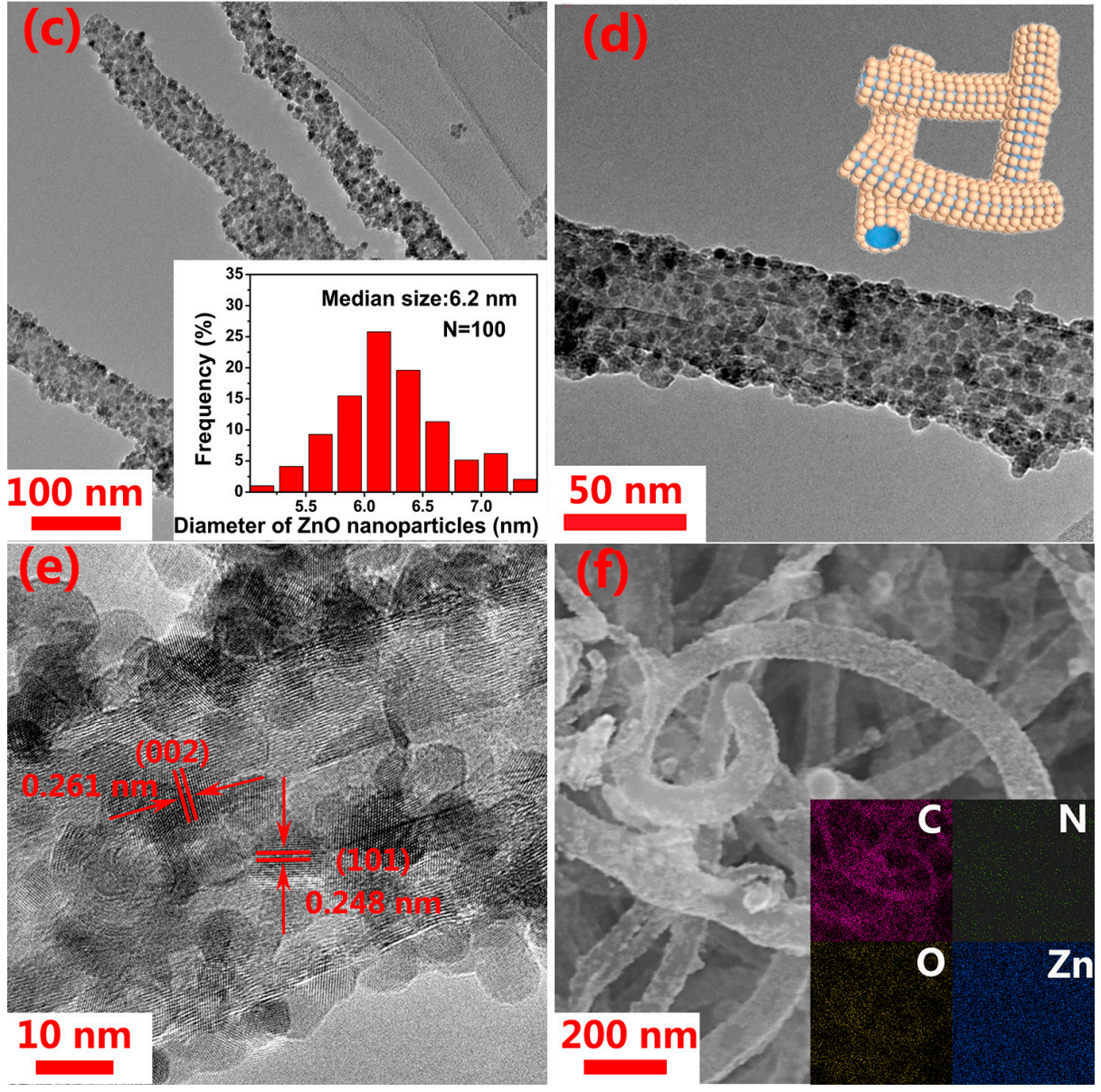

Figure 2. TEM images of (a,b) ZnO/CNT composite and (c,d) ZnO/NCNT composites with the particle size distributions (inset); (e) HR-TEM image of ZnO/NCNT composite; (f) SEM image with the EDX-mapping images (inset) of $\mathrm{ZnO} / \mathrm{NCNT}$ composite.
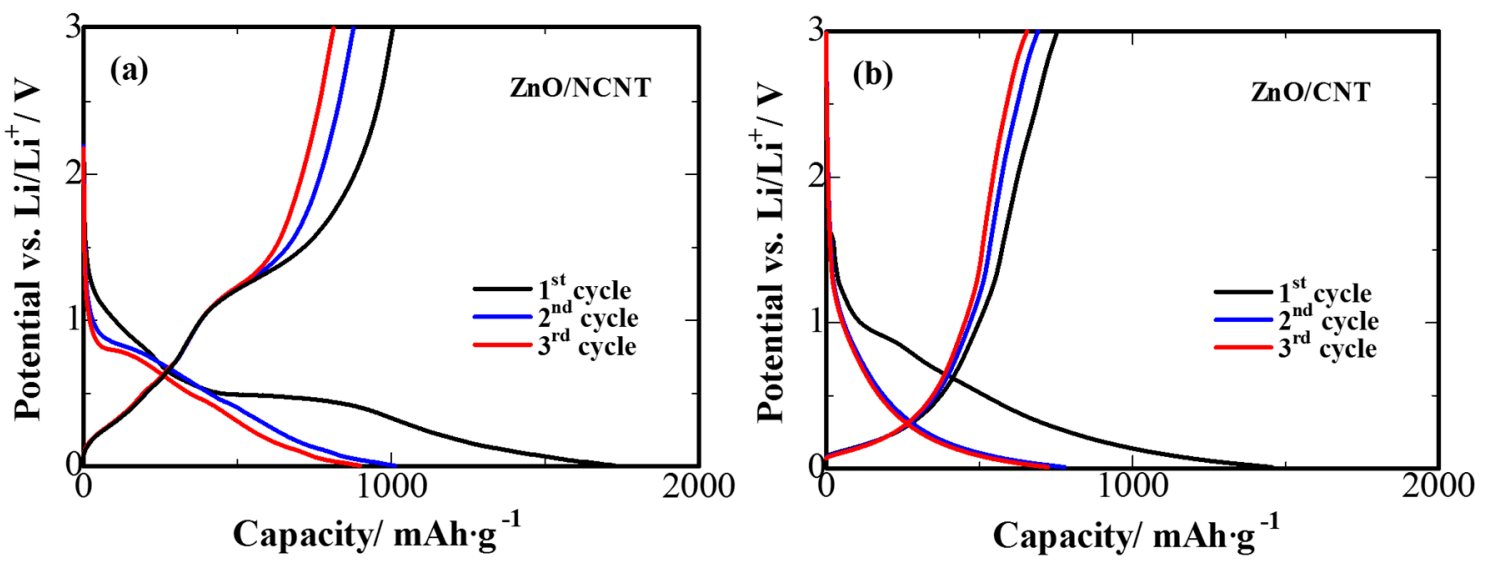

Figure 3. Initial charge/discharge curves of (a) $\mathrm{ZnO} / \mathrm{NCNT}$ and (b) $\mathrm{ZnO} / \mathrm{CNT}$ composite anodes between 0.005 and $3 \mathrm{~V}$ at current density of $100 \mathrm{~mA} \cdot \mathrm{g}^{-1}$.

Figure 4a shows the cycling ability data for the $\mathrm{ZnO} / \mathrm{NCNT}$ composite electrode and its $\mathrm{ZnO} / \mathrm{CNT}$ counterpart. One can clearly identify superior cycling stability of the $\mathrm{ZnO} / \mathrm{NCNT}$ composite. The initial reversible discharge capacity of $\mathrm{ZnO} / \mathrm{NCNT}$ composite at the second cycle is $1013 \mathrm{mAh} \cdot \mathrm{g}^{-1}$, 
and it maintains a discharge capacity of $664 \mathrm{mAh} \cdot \mathrm{g}^{-1}$ after the 100th cycle. In the same time, the $\mathrm{ZnO} / \mathrm{CNT}$ composite suffers from rapid capacity decay, losing about $34 \%$ of its second cycle capacity within 100 cycles. For pure NCNT, a reversible capacity of $220 \mathrm{mAh} \cdot \mathrm{g}^{-1}$ can be obtained after the 100th cycle, which is slightly larger than that of pure CNT. The comparison of the rate capability for the $\mathrm{ZnO} / \mathrm{NCNT}$ composite and $\mathrm{ZnO} / \mathrm{CNT}$ composite is shown in Figure $4 \mathrm{~b}$. Apparently, the discharge capacities of $\mathrm{ZnO} / \mathrm{CNT}$ composite decreases steeply with discharge rate, whereas the $\mathrm{ZnO} / \mathrm{NCNT}$ composite delivers remarkably higher discharge capacities at relative high energy densities compared with $\mathrm{ZnO} / \mathrm{CNT}$ : $558 \mathrm{mAh} \cdot \mathrm{g}^{-1}$ at a current of $400 \mathrm{~mA} \cdot \mathrm{g}^{-1}, 406 \mathrm{mAh} \cdot \mathrm{g}^{-1}$ at $800 \mathrm{~mA} \cdot \mathrm{g}^{-1}$ and $308 \mathrm{mAh} \cdot \mathrm{g}^{-1}$ at $1600 \mathrm{~mA} \cdot \mathrm{g}^{-1}$. Most notably, when the current density switched to $200 \mathrm{~mA} \cdot \mathrm{g}^{-1}$, the $\mathrm{ZnO} / \mathrm{NCNT}$ composite could recover its capacity from $308 \mathrm{mAh} \cdot \mathrm{g}^{-1}$ at $1600 \mathrm{~mA} \cdot \mathrm{g}^{-1}$ to $690 \mathrm{mAh} \cdot \mathrm{g}^{-1}$ at $200 \mathrm{~mA} \cdot \mathrm{g}^{-1}$. By contrast, the $\mathrm{ZnO} / \mathrm{CNT}$ composite displays evidently poor capacity and stability at high current densities.
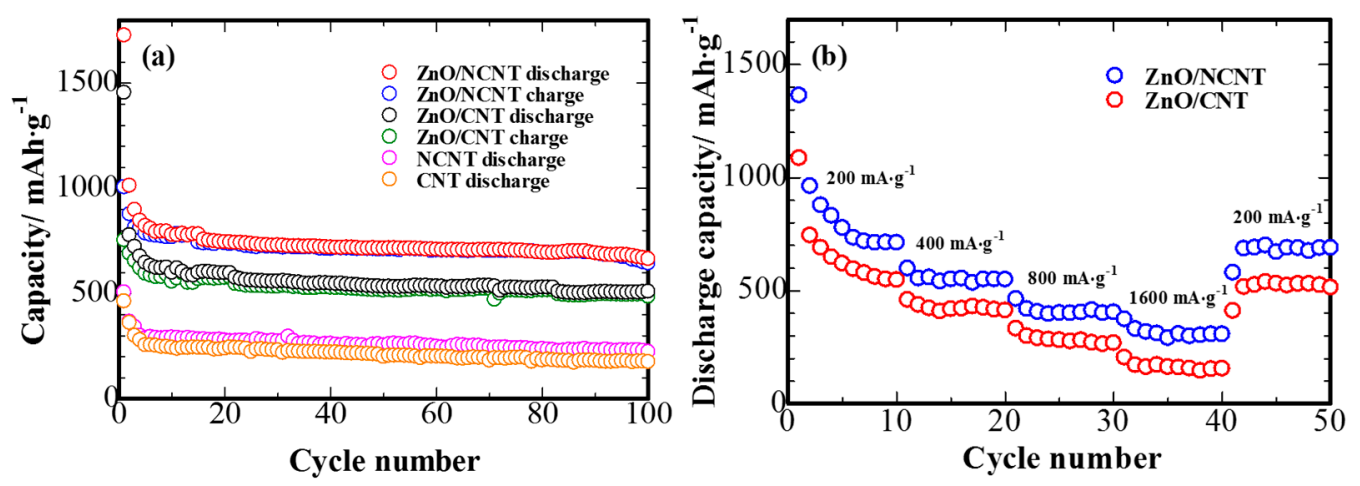

Figure 4. (a) Cycling performance of the $\mathrm{CNT}$, NCNT, $\mathrm{ZnO} / \mathrm{NCNT}$, and $\mathrm{ZnO} / \mathrm{CNT}$ anodes at a current density of $100 \mathrm{~mA} \cdot \mathrm{g}^{-1}$; (b) Rate capability of the $\mathrm{ZnO} / \mathrm{NCNT}$ and $\mathrm{ZnO} / \mathrm{CNT}$ composite anodes at different current densities from 200 to $1600 \mathrm{~mA} \cdot \mathrm{g}^{-1}$.

The improved electrochemical properties of the composite with the nitrogen doped CNT compared with the pristine CNT counterpart could be ascribed to the effect of topological defects on the NCNT [40]: Firstly, the higher concentration of nucleation sites in NCNT favors formation of the smaller size non-agglomerated $\mathrm{ZnO}$ particles with more uniform distribution on its surface: this shortens the distances for the lithium ion diffusion during the electrochemical reaction. Secondly, the doping nitrogen atoms make additional contributions due to the capability of offering an extra lone electron pair, enhancing the electrical conductivity of the system compared with the non-doped counterpart [36,41]. The synergetic positive effect of the advantages of use of nitrogen doped CNT allows for preparation of high performance composite $\mathrm{ZnO}$ anode for lithium batteries.

\section{Conclusions}

A facile process has been developed for $\mathrm{ZnO}$ nanoparticles grown on the surface of NCNT through a one-step sol-gel synthetic technique. The crystal structures and morphology of the ZnO/NCNT and $\mathrm{ZnO} / \mathrm{CNT}$ were detected by XRD patterns, SEM, and TEM images. Meanwhile, the smaller size and enlarged interlayer spacing of $\mathrm{ZnO}$ nanoparticles are dispersed more uniformly on NCNT compared with the CNT counterpart, which was caused by variation of the CNT surface by nitrogen-doping. Therefore, the $\mathrm{ZnO} / \mathrm{NCNT}$ composite exhibited an enhanced cyclability and improved rate capability as anode for LIBs. Furthermore, the present synthesis strategy provide a low-cost and efficient route to synthesize well-dispersed $\mathrm{ZnO}$ nanoparticles deposited on NCNT, which could be extended to preparation of other composite materials. 
Acknowledgments: This work was supported by the National Natural Science Foundation of China (grant number 21406052); the Program for the Outstanding Young Talents of Hebei Province (grant number BJ2014010); the Science Research Foundation for Selected Overseas Chinese Scholars, Ministry of Human Resources and Social Security of China (grant number CG2015003002); the Natural Science Foundation of Hebei Province of China (grant number E2015202037); the Science and Technology Correspondent Project of Tianjin (grant number 14JCTPJC00496); and the Ministry of Education and Science of Kazakhstan (grant number 4649/GF).

Author Contributions: Yan Zhao and Chengwei Zhang conceived and designed the experiments. Zhengjun Liu and Yuting Feng carried out the experiments. Shuang Yang and Haipeng Li analyzed the data. Zhumabay Bakenov and Fuxing Yin contributed in the drafting and revision of the manuscript. Yan Zhao and Chengwei Zhang supervised the work and finalized the manuscript. All authors read and approved the final manuscript.

Conflicts of Interest: The authors declare no conflict of interest.

\section{References}

1. Armand, M.; Tarascon, J.M. Building better batteries. Nature 2008, 451, 652-657. [CrossRef] [PubMed]

2. Zhang, Y.; Zhao, Y.; Bakenov, Z.; Babaa, M.R.; Konarov, A.; Ding, C.; Chen, P. Effect of graphene on sulfur/polyacrylonitrile nanocomposite cathode in high performance lithium/sulfur batteries. J. Electrochem. Soc. 2013, 160, A1194-A1198. [CrossRef]

3. Kundu, M.; Karunakaran, G.; Kumari, S.; Van Minh, N.; Kolesnikov, E.; Gorshenkov, M.V.; Kuznetsov, D. One-pot ultrasonic spray pyrolysis mediated hollow $\mathrm{Mg}_{0.25} \mathrm{Cu}_{0.25} \mathrm{Zn}_{0.5} \mathrm{Fe}_{2} \mathrm{O}_{4} / \mathrm{NiFe}_{2} \mathrm{O}_{4}$ nanocomposites: A promising anode material for high-performance lithium-ion battery. J. Alloys Compd. 2017, 725, 665-672. [CrossRef]

4. Kundu, M.; Karunakaran, G.; Kolesnikov, E.; Dmitry, A.; Gorshenkov, M.V.; Kuznetsov, D. Hollow $\left(\mathrm{Co}_{0.62} \mathrm{Fe}_{1.38}\right) \mathrm{FeO}_{4} / \mathrm{NiCo}_{2} \mathrm{O}_{4}$ nanoboxes with porous shell synthesized via chemical precipitation: A novel form as a high performance lithium ion battery anode. Microporous Mesoporous Mater. 2017, 247, 9-15. [CrossRef]

5. Li, H.; Li, Y.; Zhang, Y.; Zhang, C. Facile synthesis of carbon-coated $\mathrm{Fe}_{3} \mathrm{O}_{4}$ core-Shell nanoparticles as anode materials for lithium-ion batteries. J. Nanopart. Res. 2015, 17, 370. [CrossRef]

6. Poizot, P.; Laruelle, S.; Grugeon, S.; Dupont, L.; Tarascon, J.M. Nano-sized transition-metal oxides as negative-electrode materials for lithium-ion batteries. Nature 2000, 407, 496-499. [CrossRef] [PubMed]

7. Abbas, S.M.; Ali, S.; Ahmad, N.; Ali, N.; Abbas, S. Structure and electrochemical performance of ZnO/CNT composite as anode material for lithium-ion batteries. J. Mater. Sci. 2013, 48, 5429-5436. [CrossRef]

8. Zhou, Y.N.; Li, W.J.; Fu, Z.W. Electrochemical reactivity of nanocomposite ZnO-Se for lithium-ion batteries. Electrochim. Acta 2012, 59, 435-440. [CrossRef]

9. Zhang, C.Q.; Tu, J.P.; Huang, X.H.; Yuan, Y.F.; Chen, X.T.; Mao, F. Electrochemical performances of Ni-coated $\mathrm{ZnO}$ as an anode material for lithium-ion batteries. J. Solid State Chem. 2007, 154, A65-A69. [CrossRef]

10. Huang, X.H.; Xia, X.H.; Yuan, Y.F.; Zhou, F. Porous ZnO nanosheets grown on copper substrates as anodes for lithium ion batteries. Electrochim. Acta 2011, 56, 4960-4965. [CrossRef]

11. Wang, J.; Du, N.; Zhang, H.; Yu, J.; Yang, D. Layer-by-layer assembly synthesis of ZnO/SnO 2 composite nanowire arrays as high-performance anode for lithium-ion batteries. Mater. Res. Bull. 2011, 46, 2378-2384. [CrossRef]

12. Laurenti, M.; Garino, N.; Porro, S.; Fontana, M.; Gerbaldi, C. Zinc oxide nanostructures by chemical vapour deposition as anodes for Li-ion batteries. J. Alloys Compd. 2015, 640, 321-326. [CrossRef]

13. Arora, P.; White, R.E.; Doyle, M. Capacity fade mechanisms and side reactions in lithium-ion batteries. J. Electrochem. Soc. 1998, 145, 3647-3667. [CrossRef]

14. Liu, J.; Li, Y.; Ding, R.; Jiang, J.; Hu, Y.; Ji, X.; Chi, Q.; Zhu, Z.; Huang, X. Carbon/ZnO nanorod array electrode with significantly improved lithium storage capability. J. Phys. Chem. C 2009, 113, 5336-5339. [CrossRef]

15. Li, P.; Liu, Y.; Liu, J.; Li, Z.; Wu, G.; Wu, M. Facile synthesis of ZnO/mesoporous carbon nanocomposites as high-performance anode for lithium-ion battery. Chem. Eng. J. 2015, 271, 173-179. [CrossRef]

16. Hsieh, C.T.; Lin, C.Y.; Chen, Y.F.; Lin, J.S. Synthesis of ZnO@Graphene composites as anode materials for lithium ion batteries. Electrochim. Acta 2013, 111, 359-365. [CrossRef] 
17. Ren, Z.; Wang, Z.; Chen, C.; Wang, J.; Fu, X.; Fan, C.; Qian, G. Preparation of carbon-encapsulated ZnO tetrahedron as an anode material for ultralong cycle life performance lithium-ion batteries. Electrochim. Acta 2014, 146, 52-59. [CrossRef]

18. Guler, M.O.; Cetinkaya, T.; Tocoglu, U.; Akbulut, H. Electrochemical performance of MWCNT reinforced $\mathrm{ZnO}$ anodes for Li-ion batteries. Microelectron. Eng. 2014, 118, 54-60. [CrossRef]

19. Sui, J.; Zhang, C.; Hong, D.; Li, J.; Cheng, Q.; Li, Z.; Cai, W. Facile synthesis of MWCNT-ZnFe $\mathrm{O}_{4}$ nanocomposites as anode materials for lithium ion batteries. J. Mater. Chem. 2012, 22, 13674-13681. [CrossRef]

20. Yang, L.; Hu, J.; Dong, A.; Yang, D. Novel $\mathrm{Fe}_{3} \mathrm{O}_{4}-\mathrm{CNTs}$ nanocomposite for Li-ion batteries with enhanced electrochemical performance. Electrochim. Acta 2014, 144, 235-242. [CrossRef]

21. Jeong, Y.; Lee, K.; Kim, K.; Kim, S. Pore-structure-optimized cnt-carbon nanofibers from starch for rechargeable lithium batteries. Materials 2016, 9, 995. [CrossRef] [PubMed]

22. Qin, X.; Zhang, H.; Wu, J.; Chu, X.; He, Y.B.; Han, C.; Miao, C.; Wang, S.; Li, B.; Kang, F. Fe ${ }_{3} \mathrm{O}_{4}$ nanoparticles encapsulated in electrospun porous carbon fibers with a compact shell as high-performance anode for lithium ion batteries. Carbon 2015, 87, 347-356. [CrossRef]

23. Liu, H.; Zhang, Y.; Li, R.; Sun, X.; Désilets, S.; Abou-Rachid, H.; Jaidann, M.; Lussier, L.S. Structural and morphological control of aligned nitrogen-doped carbon nanotubes. Carbon 2010, 48, 1498-1507. [CrossRef]

24. Mi, R.; Liu, H.; Wang, H.; Wong, K.W.; Mei, J.; Chen, Y.; Lau, W.M.; Yan, H. Effects of nitrogen-doped carbon nanotubes on the discharge performance of Li-air batteries. Carbon 2014, 67, 744-752. [CrossRef]

25. Zhao, Y.; Yin, F.; Zhang, Y.; Zhang, C.; Mentbayeva, A.; Umirov, N.; Xie, H.; Bakenov, Z. A free-standing sulfur/nitrogen-doped carbon nanotube electrode for high-performance lithium/sulfur batteries. Nanoscale Res. Lett. 2015, 10, 450. [CrossRef] [PubMed]

26. Zhao, Y.; Bakenova, Z.; Zhang, Y.; Peng, H.; Xie, H.; Bakenov, Z. High performance sulfur/nitrogen-doped graphene cathode for lithium/sulfur batteries. Ionics 2015, 21, 1925-1930. [CrossRef]

27. Tao, H.C.; Yang, X.L.; Zhang, L.L.; Ni, S.B. One-step synthesis of nickel sulfide/N-doped graphene composite as anode materials for lithium ion batteries. J. Electroanal. Chem. 2015, 739, 36-42. [CrossRef]

28. Li, H.; Wei, Y.; Zhang, Y.; Zhang, C.; Wang, G.; Zhao, Y.; Yin, F.; Bakenov, Z. In situ sol-gel synthesis of ultrafine $\mathrm{ZnO}$ nanocrystals anchored on graphene as anode material for lithium-ion batteries. Ceram. Int. 2016, 42, 12371-12377. [CrossRef]

29. Li, H.; Wei, Y.; Zhao, Y.; Zhang, Y.; Yin, F.; Zhang, C.; Bakenov, Z. Simple one-pot synthesis of hexagonal ZnO nanoplates as anode material for lithium-ion batteries. J. Nanomater. 2016, 2016, 4675960. [CrossRef]

30. Wang, S.; Zhou, S. Photodegradation of methyl orange by photocatalyst of CNTs/P-TiO(2) under uv and visible-light irradiation. J. Hazard. Mater. 2011, 185, 77. [CrossRef] [PubMed]

31. Hu, C.; Guo, S.; Lu, G.; Fu, Y.; Liu, J.; Wei, H.; Yan, X.; Wang, Y.; Guo, Z. Carbon coating and $\mathrm{Zn}^{2+}$ doping of magnetite nanorods for enhanced electrochemical energy storage. Electrochim. Acta 2014, 148, 118-126. [CrossRef]

32. Zhang, S.; Yu, X.; Yu, H.; Chen, Y.; Gao, P.; Li, C.; Zhu, C. Growth of ultrathin MoS $_{2}$ nanosheets with expanded spacing of (002) plane on carbon nanotubes for high-performance sodium-ion battery anodes. ACS Appl. Mater. Interfaces 2014, 6, 21880. [CrossRef] [PubMed]

33. Yue, H.; Wang, Q.; Shi, Z.; Ma, C.; Ding, Y.; Huo, N.; Zhang, J.; Yang, S. Porous hierarchical nitrogen-doped carbon coated $\mathrm{ZnFe}_{2} \mathrm{O}_{4}$ composites as high performance anode materials for lithium ion batteries. Electrochim. Acta 2015, 180, 622-628. [CrossRef]

34. Zhang, T.; Zhong, B.; Yang, J.Q.; Huang, X.X.; Wen, G. Boron and nitrogen doped carbon nanotubes $/ \mathrm{Fe}_{3} \mathrm{O}_{4}$ composite architectures with microwave absorption property. Ceram. Int. 2015, 41, 8163-8170. [CrossRef]

35. Song, J.; Xu, T.; Gordin, M.L.; Zhu, P.; Lv, D.; Jiang, Y.B.; Chen, Y.; Duan, Y.; Wang, D. Nitrogen-doped mesoporous carbon promoted chemical adsorption of sulfur and fabrication of high-areal-capacity sulfur cathode with exceptional cycling stability for lithium-sulfur batteries. Adv. Funct. Mater. 2014, 24, 1243-1250. [CrossRef]

36. Cai, D.; Li, D.; Wang, S.; Zhu, X.; Yang, W.; Zhang, S.; Wang, H. High rate capability of TiO 2 /nitrogen-doped graphene nanocomposite as an anode material for lithium-ion batteries. J. Alloys Compd. 2013, 561, 54-58. [CrossRef] 
37. Dai, J.; Wang, M.; Song, M.; Li, P.; Zhang, C.; Xie, A.; Shen, Y. A novel synthesis of ZnO/N-doped reduced graphene oxide composite as superior anode material for lithium-ion batteries. Scr. Mater. 2016, 112, 67-70. [CrossRef]

38. Yan, J.; Wang, G.; Wang, H.; Zhang, Z.; Ruan, X.; Zhao, W.; Yun, J.; Xu, M. Preparation and electrochemical performance of bramble-like $\mathrm{ZnO}$ array as anode materials for lithium-ion batteries. J. Nanopart. Res. 2015, 17, 1-10. [CrossRef]

39. Bai, Z.; Zhang, Y.; Fan, N.; Guo, C.; Tang, B. One-step synthesis of ZnO@C nanospheres and their enhanced performance for lithium-ion batteries. Mater. Lett. 2014, 119, 16-19. [CrossRef]

40. Cai, D.; Wang, S.; Lian, P.; Zhu, X.; Li, D.; Yang, W.; Wang, H. Superhigh capacity and rate capability of high-level nitrogen-doped graphene sheets as anode materials for lithium-ion batteries. Electrochim. Acta 2013, 90, 492-497. [CrossRef]

41. Du, M.; Xu, C.; Sun, J.; Gao, L. One step synthesis of $\mathrm{Fe}_{2} \mathrm{O}_{3} /$ nitrogen-doped graphene composite as anode materials for lithium ion batteries. Electrochim. Acta 2012, 80, 302-307. [CrossRef]

(C) 2017 by the authors. Licensee MDPI, Basel, Switzerland. This article is an open access article distributed under the terms and conditions of the Creative Commons Attribution (CC BY) license (http://creativecommons.org/licenses/by/4.0/). 